\title{
Problems of Border Regions in Ensuring Legal Certainty Invest in Indonesia
}

\author{
Rieka Lieke Lontoh
}

\author{
Faculty of Law, Universitas Katolik De La Salle Manado
}

email: rietha_lontoh@yahoo.com

\begin{abstract}
The mandate of Article 33 of the 1945 Constitution of the Republic of Indonesia maximizes all elements of development as an effort to realize the people's prosperity through the development of law in the field of investment in the perspective of regional autonomy in the border regions of the Republic of Indonesia. Border areas are a problem because legal certainty for investors has yet to find a meeting point for investment, especially in border areas, so it seems that government responsibilities are still minimal in efforts to equalize the welfare of its people. Normative juridical research methods using secondary legal materials produce a coherent legal science research in finding the truth, and the results of this study suggest that legal certainty does not accommodate the interests of development in border areas, causing a chain problem and an investment climate improvement is based on the fact that the lack the interest of foreign investors in Indonesia is caused by various obstacles, which in turn hinder the business of investors or cause the transfer of business to other countries. The author concludes to overcome economic problems, especially in investing, the government takes steps to encourage the competitiveness of national industries, through deregulation, bureaucratization, and law enforcement and business certainty. Therefore, through this paper, it is necessary to reform the legal rules by preparing regional regulations, especially in North Sulawesi relating to investment management in the border region, as a sample of study material that can provide legal certainty and protection for investors throughout Indonesia.
\end{abstract}

Keywords : Investation; Regional Autonomy; Border Area

\section{INTRODUCTION}

Article 33 of the 1945 Constitution of the Republic of Indonesia whose purpose is for the welfare of the people, all potentials in the field of economic development, especially earth, water, and natural wealth must be maximized as the maximum goal is for the prosperity of the people. The highest authority holder, the interests of the people must be prioritized by involving the State as the movers, organizers and executors of development with the aim of the people's prosperity, as the National Development Vision and mission of 2005 2025 refers to the country's goals as outlined in Chapter III of the Republic of Indonesia Number 17 in 2007 concerning the National Long-Term Development Plan and the core of a just, prosperous, and independent nation that is also the driving force, implementer and object of national development, the people also have the right to enjoy the results of development all of which are carried out for the benefit of the people by the people and 
for the people who prioritize justice in nation-building. The stream of expediency with the motto "the greatest happiness of the greatest number" emphasizes the importance of government intervention to create maximum happiness for many people. ${ }^{1}$ Vision and mission will be realized if optimally and the potential possessed by maximizing natural resources as the main capital of national development

An important task of the government is to realize Indonesia as a welfare state with the aim of advancing public welfare and social justice, namely by establishing various public policies in order to improve social welfare. This does not conflict with the thought of the flow of law that emphasizes the achievement of happiness as much as possible for many people, known as utilitarianism. Utility theory states that the law aims to realize only what is beneficial. ${ }^{2}$ Good and bad law in managing a country's economy must be measured by the merits of the consequences resulting from the application of the law. This means that a new legal provision can be judged well if the consequences resulting from its application are good, maximum happiness and less suffering. ${ }^{3}$

The economic growth of a region also depends on the geographical factors of a region. The geostrategic concept is not associated with the development of the concept of development policies and strategies that motivated the economic benefits, but also capable of bringing glory development of a country in various fields who not only seek economic profit as the main objective, but also build strength, influence, and the glory of the country. ${ }^{4}$

The implementation of government affairs by the regional government is carried out based on the principle of autonomy and co-administration, which means that the rights, authorities and obligations of the autonomous region to regulate and manage their own government affairs and the interests of the local community, because the government realizes that central government affairs which are the authority of the central government cannot possibly be carried out as well as possible by the central government in the interests of public service governance and the welfare of the people in all regions. Considering the geographical, political, legal, social and cultural conditions that are very diverse and patterned, and the territory of the Unitary Republic of Indonesia is so broad that it encompasses various islands, it is very appropriate to provide autonomous policies so that each region will be more capable and independent to provide service and improvement of people's welfare in the area. This change and development is a characteristic of the modern state which places more emphasis on improving people's welfare. ${ }^{5}$

\footnotetext{
${ }^{1}$ Riyanto, Astim. (2003). Filsafat Hukum. Bandung: Yapemdo, p. 265.

2Syahrani, Riduan. (2004). Rangkuman Intisari Ilmu Hukum. Bandung: PT. Citra Aditya Bakti, p. 22.

${ }^{3}$ Rasjidi, Lili, \& Putra, I. B. Wyasa. (2003). Hukum Sebagai Suatu Sistem. Bandung: CV. Mandar Maju, pp. $116-117$.

${ }^{4}$ Sarundajang, Sinyo Harry, \& Kuncoro, Mudrajad. (2011). Geostrategi: Sulawesi Utara Menuju Pintu Gerbang Indonesia di Asia Pasifik. Jakarta: Kata Hasta Pustaka, p. 11.

${ }^{5}$ Manan, Bagir. (2001). Menyongsong Fajar Otonomi Daerah. Yogyakarta: UII Press, p. 83.
} 
Local governments are required as a public servant, stimulator, facilitator, catalyst, and managers who have the entrepreneurial spirit to the development process and increase social welfare. ${ }^{6}$ The participation of investors in the management of natural potentials are expected to help the government to manage and develop all economic power has an important role in improving the prosperity and welfare as well as provide real added value to the national economy.

One effort to increase investment in Indonesia is rearranging the rules of law, especially concerning the problem of investment to attract as many investors entered invest in Indonesia. Investors in running her business require legal certainty in investing activities so that things that have been agreed can be implemented according to the rules. Legal certainty provides legal protection for investors in investing in a form of confidence in the establishment of the legal relationship between investors who are willing to invest the capital recipient. ${ }^{7}$

Investment activities in Indonesia have often complained of by the investor which is associated with licensing issues, security, employment, law enforcement, and so forth This is to say that the investment climate in Indonesia is not conducive for investors when investing risky nature of activity so that investment activity should be supported by rules that create legal certainty, promoting justice, fair and efficient, because the principles of this law create the reasonableness and the tranquillity of life. ${ }^{8}$

Legal certainty for investors is a necessity that can't be bargained again as investors, in addition, is subject to the investment law is also subject to other regulations related to investment such labour, taxes, license, land issues that serve as a material consideration in investors invest their capital. An assurance on the implementation of clear and strict rules that is the appeal of investors for their atmosphere is conducive for their investment capital remains safe so that investors can comfortably work in Indonesia.

Efforts to support increased investment, especially foreign investment, this law carries several principles including, that there is no different application between foreign investment and domestic investment, there are no restrictions on control of the public sector, including arrangements aimed at sector development and protection, to be associated with regional development, technology transfer to the development of Small and Medium Enterprises. Even this law brings the spirit of liberalization related to the opportunity for investors to transfer and repatriate capital freely and guarantee free nationalization. ${ }^{9}$ This is done as an effort to attract as much foreign capital as possible to support economic

\footnotetext{
${ }^{6}$ Mardiasmo. (2004). Otonomi dan Manajemen Keuangan Daerah. Yogyakarta: CV. Andi Offset, p. 59. 123.

S., Salim H., \& Sutrisno, Budi. (2008). Hukum Investasi di Indonesia. Jakarta: PT. Raja Grafindo Persada, p.

${ }^{8}$ Atmosudirdjo, S. Prajudi. (1990). Dasar-Dasar Administrasi Negara. Jakarta: Ghalia Indonesia, p. 26.

${ }^{9}$ Vide Article 8 of Law of the Republic of Indonesia Number 25 of 2007 (Law No. 25 of 2007) concerning Investment.
} 
development in Indonesia. Then this Investment Law also makes it easy for investors in terms of services and/or licensing of land rights as referred to in Article 21 letter "a" can be granted and extended upfront at the same time and can be renewed at the request of investment, in the form of cultivation rights title, and right to use title.

Favourable investment climate conducive to investment activity in Indonesia is reflected in the legal field of the capital market is good so it has international competitiveness will thus provide more free space in order to capital, technology and labour can move easily between regions of the country. Moreover, if it is associated with the ongoing globalization process in the world that requires local international have competitive readiness, both nationally and internationally. ${ }^{10}$

Minimal infrastructure in the border regions has shown that the government does not have a serious concern with border management systems that can support the economic improvement of the people in the form of investment. The existence of the welfare state can not be separated from the role of government that is responsive to the management and organization of the economy to carry out its responsibility to ensure the availability of basic welfare services in a certain level for its citizens. ${ }^{11}$ Development policies still pay less attention to border areas and are more directed towards areas that are densely populated, have easy and potential access, while development policies for remote, isolated and disadvantaged areas such as border areas are still not prioritized.

Border issues have a complex dimension, there are some crucial factors involved in them, such as jurisdiction and sovereignty of the state, political, social, economic, and defence and security. Handling various problems still faces various obstacles, especially those related. This causes a lack of attractiveness for business actors to carry out their economic activities in the border regions of Indonesia, with institutional aspects, because it has been neglected for a long period, the border region in Indonesia has been considered to have a negative image in the eyes of the world. The negative image created is a result of the border area being made as a place where the problems of illegal workers (illegal workers), logging and deforestation (illegal logging), and smuggling (smuggling). Also the underdeveloped development in the border region and the emergence of tensions as a result of the isolation of the region, causing this area can be an entry point for the escape of terrorists who are concerned about the international world (transnational-terrorists). ${ }^{12}$ So this research attempts to answer the research results and becomes the formulation of the problem: How is the guarantee of legal certainty that provides legal protection for investors in the implementation of investment in Indonesia?

\footnotetext{
${ }^{10}$ Tjokroamidjojo, Bintoro. (2000). Good Governance: Paradigma Baru Manajemen Pembangunan. Jakarta: UI Press, p. 2.

${ }^{11}$ Samidjo. (1986). Ilmu Negara. Bandung: CV. Armico, p. 57.

${ }^{12}$ Kemitraan Partnership. (2011). Kebijakan Pengelolaan Kawasan Perbatasan Indonesia. In Partnership Policy Paper No. 2/2011. Jakarta: The Partnership for Governance Reform, p. 4. Retrieved from http://www.kemitraan. or.id/policy-paper-no-22011-kebijakan-pengelolaan-kawasan-perbatasan/\#
} 


\section{METHOD}

This study uses the type of normative juridical research as legal science research methods. This research approach uses the primary source of secondary data in completing research, derived from a literature review that consists of some literature that can be assessed as a result of the study as legal science. Approach this type of research efforts to find a law in concreto which aims to apply the appropriate law in addressing a particular issue. Also, the historical approach complements of this article so descriptive-analytical nature biodegradable systematic and coherent in breaking down this article.

\section{ANALYSIS AND DISCUSSION}

\section{A. Legal Certainty Guarantee to Provides Legal Protection for Investors in the Implementation of Investment in Indonesia}

Investment and economic law are two systems of the social system that interact with one another. The law is a set of norms that govern the relations of economic activity and is substantially influenced by the economic system used by the country concerned, whether liberalistic, socialist or mixed. ${ }^{13}$ However, according to the author's opinion that the scope of the Investment Law cannot be separated from Article 33 of the 1945 Constitution of the Republic of Indonesia, which is the legal basis for Indonesian economic activities.

Stated in the 1945 Constitution of the Republic of Indonesia, there are 2 articles that can be used as guidelines for the economic structure aspired by Indonesia, namely Article 27 Paragraph (1) and Paragraph (2) and Article 33, both articles show that there are 5 the principle which is the main characteristic of the Indonesian Economic System, namely the principle of equality in law (Article 27 Paragraph (1)), the principle of humanity (Article 27 Paragraph (2)), the principle of kinship (Article 33 Paragraph (1)), the principle of balance (Article 33 Paragraph (2)) and the principle of benefits (Article 33 Paragraph (3)). ${ }^{14}$

Every opinion about investment laws have specific reasons based on differences in the angle of reviews, but most importantly by the authors is how the investment law systemic role in the economic development of Indonesia, especially in the border region so that the purpose of the establishment of the State of Indonesia as already stated emphatically in the Fourth paragraph of the 1945 Constitution of the Republic of Indonesia can be achieved. Indonesia's economic development activities should be based on the provisions of the law, so that the limited economic resources can be utilized for the prosperity of the people of Indonesia based on justice. $16-17$

${ }^{3}$ Hartono, C. F. G. Sunaryati. (1985). Hukum Ekonomi Pembangunan Indonesia. Bandung: Bina Cipta, pp.

${ }^{14}$ Saleh, Ismail. (1990). Peranan Konglomerasi sebagai Pelaku Ekonomi dalam Rangka Pembangunan Nasional. In Pokok-Pokok Pikiran mengenai Pengaturan Persaingan Sehat di Dunia Usaha (20 February ed.). Jakarta: Universitas Tarumanagara, p. 63. 
Indonesian investment law should be supported toward the regulation of economic development activities in Indonesia systemically, which in turn will provide certainty in the implementation of the legal relationship to the activities of the Indonesian economy, among others, by creating rights and obligations for legal subjects. Legal certainty in the economy, especially investment or investment, is an absolute demand and is the main driving force for attracting foreign investors to invest their capital. The existence of a good legal infrastructure, which consists of a set of rules, institutions and processes that realize the enactment of such rules fact, allow for the proper functioning of the economic system. ${ }^{15}$

Various opinions of experts on the role and function of law in national development include the opinion of Mochtar Kusumaatmadja who said that the role of law in economic development can be seen from the main purpose of law, namely order, as a basic requirement for the existence of an organized human society, ${ }^{16}$ the role of important law in achieving justice, which is essentially rooted in a condition that at a certain time desired by a certain society, ${ }^{17}$ and there are four legal functions in national development: ${ }^{18}$

1. Law as a preserver of order and security.

2. The law as a means of development.

3. The law as a means of justice.

4. Law as a means of public education.

Investment or investment law as described above cannot be separated from international economic law. The Indonesian economy as an open economic system has economic relations with other countries in the world, which are characterized, at least, by the activities of Indonesia's export and import trade with these countries. Conducting international trade is an activity that is commonly done by various countries. ${ }^{19}$ Likewise, the flow of investment from one country to another, both directly and indirectly or the movement of capital owners from one country to another (movement natural persons), is part of international economic activity.

A welfare state like Indonesia, investment law has a role in economic development. Economic development is aimed at achieving the objectives of the welfare state, taking into account broad employment opportunities through an opening as many economic activity units as possible. All of that requires direct capital flows

\footnotetext{
${ }^{15}$ Kusumaatmadja, Mochtar. (2002). Konsep-Konsep Hukum dalam Pembangunan (Otje Salman \& Eddy Damian Eds.). Bandung: PT. Alumni, p. 10.

${ }^{16} \mathrm{lbid}$.

${ }^{17}$ Soekanto, Soerjono. (1976). Beberapa Permasalahan Hukum dalam Kerangka Pembangunan di Indonesia. Jakarta: Yayasan Penerbit Universitas Indonesia, pp. 4 - 5.

${ }^{18 H a r t o n o, ~ C . ~ F . ~ G . ~ S u n a r y a t i . ~(1985) . ~ O p . ~ C i t ., ~ p . ~} 8$.

${ }^{19}$ Sukirno, Sadono. (2006). Ekonomi Pembangunan: Proses, Masalah, dan Dasar Kebijakan. Jakarta: Kencana Prenada Media Group, pp. 202 \& 222.
} 
(direct investment), both sourced from within the country (domestic direct investment) and from abroad (foreign direct investment). Indonesia's economic development is carried out in accordance with the National Development Planning System, which was compiled in the Law of the Republic of Indonesia Number 25 of 2004 concerning the National Development Planning System, with one of the considerations that the government of the Indonesian state was formed to protect all the people of Indonesia and all of Indonesia's blood spills, advancing general welfare, educating the nation's life and participating in carrying out world order. A more detailed description of the National Development Planning System is contained in the form of Law No. 17 of 2007 concerning the National Long-Term Development Plan 2005 - 2025 (RPJPN 2005 - 2025) and is now in the third period as outlined in the Republic of Indonesia Presidential Regulation (Perpres) Number 2 of 2015 concerning the 2015 - 2019 National Medium-Term Development Plan.

Improving the investment climate is based on the fact that the lack of interest of foreign investors to Indonesia due to various constraints, which in turn inhibits the efforts of investors or cause the transfer of business to another country. The problems faced by, among others:

1. The lack of legal certainty among others, reflected a delay in settlement of cases of investment,

2. The licensing procedure and manner of bureaucratic service, takes time and is expensive,

3. The lack of investment incentives granted,

4. Uneven infrastructure and damage to a number of infrastructure in the regions have hampered the smooth expedition and distribution of people, goods and capital for investment activities,

5. The employment climate less conducive to supporting the investment activities that include quality up to wage.

Investment activities are defined as capital formation in the form of expenditures made by investors to purchase capital goods and production equipment to increase the ability to produce goods and services available in a country's economy, and economic growth in a country can occur if supported by there is an investment flow (direct investment) in the country. The presence of direct investment in general provides positive benefits for the host country, consumers and local business partners in the investment destination country.

Indonesia's economic system showed that Indonesia's economic development can't be separated from international economic activities. The presence of the Investment Law is an example that Indonesia's economic development cannot be carried out on its own. The presence of foreign capital in Indonesia's economic development is a 
necessity, as appropriate with other countries such as China and India. To find out how the role of foreign investment in the Indonesian economy is still relatively little research conducted to measure specifically the role of foreign investment.

Since the enactment of the Foreign Investment Law in 1967 and replaced with Law of the Republic of Indonesia Number 25 of 2007 concerning Investment, investment development both in terms of the total investment value and the number of companies per year, fluctuates from year to year. Fluctuations both in terms of value and number of companies heavily influenced by Government policy in the field of foreign investment both foreign and domestic, from time to time, have ups and downs, which means that at any given moment, discretion is rigorous but at other times relatively loose.

The law contains the norms that regulate, govern, force and prohibit and so on. The norm does not understand whether the norm will be effective or not. Term development of the law has a broader meaning, thorough and fundamental than the term law reform, legal guidance. Legal reform implies constructing a legal system to adjust to changing society.

Economic growth activities are strongly supported by development funds that can be obtained through savings and investment activities. This investment activity influences contributing to economic growth. The law is very instrumental in increasing economic efficiency through investment activities, for example, that the rule of law that provides guarantees of certainty will attract investors.

Economic development resulted in a fundamental shift in world trade. This not only has a significant impact on the country but also on all forms of regional and multilateral cooperation. Investment is a key enabler which can encourage the growth of industry and trade sector activities and the creation of a good balance between sectors and trade as well as the creation of a balance across sectors and economic actors in restoring economic growth. ${ }^{20}$ Investment activities or investments both foreign and domestic have an impact on economic growth, this is due to the development of capital from government sources that there are limitations to investment must be minimized and reorganized. Legal certainty can give a value for the investor to take their investment policies. If the investment activities in Indonesia have a good opportunity, in the sense of a very high level of investment return for investors it is a fortune.

\section{B. Legal Arrangements Investment Gives Certainty and Legal Protection for Investors}

Following the nature of the law that is the law that regulates also the law that resolves disputes. Legal certainty is created by written regulations made by the

\footnotetext{
${ }^{20}$ Halwani, Hendra. (2002). Ekonomi Internasional dan Globalisasi Ekonomi. Bogor: Ghalia Indonesia, p. 68.
} 
central and regional governments as a form of government seriousness in improving the economy of the community by providing legal certainty as stipulated in Law of the Republic of Indonesia Number 25 of 2007 concerning Investment in Article 4 Paragraph (2) b which states that "the state guarantees legal certainty, business certainty and business security for investors from the process of licensing until the end of investment activities in accordance with statutory provisions."

Law enforcement in the field of investment is often a question of investors.

Does the investment activity have the value of certainty and legal protection for investors? This is important because investors often want legal certainty in investing.

The law was a major contributor to the validity of investing activities, namely to provide protection, legal certainty and fairness. This argument is based on an understanding that more attractive investment activity creating adequate infrastructure investment, including administrative and legal infrastructure than giving tax incentives for long term investment. The legal and development context places the laws and regulations as the main legal sources. ${ }^{21}$

Law as the main contributor in the validity of development activities must be able to provide legal protection and certainty, otherwise if the law does not support or the law is compiled and/or formulated by not using good legal principles, for example disobeying the principle, in the procedures for drafting regulations, disobeying the principles in application of legislation, this will have an impact on uncertainty and legal protection. The main source of law in development is legislation, so if there is legislation that does not adhere to the principles in the preparation and formulation of norms, then the legal regulations do not support the concept of development law. Legal certainty can provide a sense of order, peace and security if the community is involved in it. The consequence is that the law must have credibility by showing consistency flow if it is not consistent then the community will not rely on it as a set of norms that govern common life. ${ }^{22}$ The concept of law and development in Indonesia emphasizes that the main source of law is legislation. The law in providing the value of legal certainty to the community is something that must be done and implemented because the provision of legal certainty through the law must also pay attention to regional autonomy because currently the region is given the authority to explore and develop the potential of the region.

The habit of giving the job without going through the exact mechanism is very contrary to the principles of good governance, the transparency necessary with appropriate regulations. The principle of legal certainty itself is at least an aspect of legal certainty in the form of a decision that must be clearly formulated so that pp. $150-151$. 
understanding of the decision does not depend on one's interpretation, not multiple interpretations so that everyone who faces the decision must be able to grasp what is meant in the decision. ${ }^{23},{ }^{24}$ Another important investment activity is obedience in contract matters, because if not, then it is an indicator of violations of legal protection due to lack of legal certainty.

The Indonesian people have explicitly stated in the 1945 Constitution of the Republic of Indonesia that Indonesia is a state of law, this means that all activities must be based on existing legal norms, including investors and recipients of capital in carrying out business activities in it is investing. This means that if an investor is going to make an investment in addition to having to pay attention to investment law, he must also understand the various provisions related to investment because it is important to know that the rules are made so that those who will enter the business realm to be carried out already understand the rules set. ${ }^{25}$

If a company that has obtained a business license by considering the benefits that will be obtained when running a business that has received an investment license is suddenly revoked its license, in this case it requires consistency and consequences in granting a license so that it does not violate the established legal signs so that investors feel comfortable in investing. The principle is that the relationship between investors as owners of capital and recipients of capital is very closely related because investors will be willing to invest their capital if the state as a recipient of capital can provide and guarantee legal certainty, legal protection and a sense of investment security. In the absence of legal certainty, legal protection and security it is impossible for an investor is willing to invest. ${ }^{26}$ But in reality the judge also provides multi-interpretation of the rule, for example in derivative agreements in the stock market, on the one hand derivative agreements is justified by the Act but often judges rests on the provisions of articles contained in the draft Civil Code that does not justify derivative agreements because it is categorized as a profit agreement, conducive regulations are needed that can provide protection and legal certainty in carrying out investment activities in Indonesia.

Economic development must be carried out in a consistent, joint and complementary and supportive manner so that growth leading to stable economic development increases to produce a just and prosperous state goal. ${ }^{27}$ Economic achievement in improving the lives of many people certainly cannot be separated from

${ }^{23}$ Fahmal, A. Muin. (2006). Peran Asas-Asas Umum Pemerintahan yang Layak dalam Mewujudkan Pemerintahan yang Bersih. Yogyakarta: UII Press, p. 32.

${ }^{24}$ Indroharto. (1994). Pentingnya Asas-Asas Umum Pemerintahan yang Baik. In Paulus Effendi Lotulung (Ed.), Asas-Asas Umum Pemerintahan yang Baik. Bandung: PT. Citra Aditya Bakti, p.147.

${ }^{25}$ Margono, Sujud. (2008). Hukum Investasi Asing Indonesia. Jakarta: Novindo Pustaka Mandiri, p. 15.

${ }^{26}$ Sembiring, Sentosa. (2010). Hukum Investasi: Pembahasan Dilengkapi dengan UU Nomor 25 Tahun 2007 tentang Penanaman Modal. Bandung: Nuansa Aulia, p. 15.

${ }^{27}$ Baharuddin, Hamzah. (2008). Hak Gugat Lembaga Swadaya Masyarakat (LSM) dalam Rangka Kontrol terhadap Pelayanan Publik. Makassar: PT. Umitoha Ukhuwah Grafika, p. 21. 
the understanding that the law is an economic tool in upholding rights, protection for the community, especially economic actors so that they can invest safely and protected. Improvement of people's welfare has a very broad dimension, encompassing all fields of life that directly or indirectly involve human dignity. ${ }^{28}$

If an economic activity, in this case, the investment provides legal protection in the form of legal certainty, it will have a positive impact on economic development in the country of Indonesia. Development of the law consistently and planning is one of the most important keys to the development of the national economy to raise the image and credibility of the country in the eyes of foreign investors and domestic. Appropriate law enforcement functions and mandate than the impact on the development of the national economy. The running of the legal function in business activities will provide certainty and legal protection because legal certainty and clear protection will provide motivation for economic actors to invest, both investing in the capital market, general trade, and other forms of business.

Increasing the confidence of entrepreneurs because of legal protection will determine business considerations rationally and will drive the economic wheel, economic structure, become better and increase the state revenue sector. Ensuring legal certainty will positively impact the arrival of foreign and local investors in doing business in Indonesia because of the credibility of the country used as a benchmark for their business development.

Application in providing legal certainty guarantees and legal protection for investors, the services provided in the form of a one-stop service pattern with the issuance of Presidential Regulation No. 97 of 2014 concerning the Implementation of One-Stop Integrated Services implemented by the regions with the formation of government institutions that will take care of, develop and creating an integrated licensing system with fast, efficient and effective services for investors by referring to regulations on licensing guidelines and procedures for investment facilities and regulations on guidelines and procedures for controlling investment implementation. ${ }^{29}$

This licensing system involves aspects of legality which include the validity of the objectives, authority, procedures, substance, law enforcement so that with the existence of this legality aspect, it will provide legal protection for investors. Following the functions of government to regulate and protect, licenses aim to restrict the freedom of individual activity. Privileges limit should not abandon the rule of law is the principle of legality and is therefore authorized to grant permission must refer to the legislation.

\footnotetext{
${ }^{28}$ Siagian, Sondang P. (2005). Administrasi Pembangunan: Konsep, Dimensi, dan Strateginya. Jakarta: Bumi Aksara, p. 138

${ }^{29}$ Vide Regulations of the Capital Investment Coordinating Board of the Republic of Indonesia Number 6 of 2018 concerning Guidelines and Procedures for Licensing and Investment Facilities, and Regulations of the Capital Investment Coordinating Board of the Republic of Indonesia Number 7 of 2018 concerning Guidelines and Procedures for Controlling the Implementation of Investment.
} 
The authority to grant license according to administrative law consists of, the attribution authority is the authority attached to a position because of the law, then the delegation authority is the delegated authority so that it can be said that the attribution and delegation authority is the authority to control whether a particular body is authorized or not. ${ }^{30} \mathrm{~A}$ license must fulfill the validity of the procedure which can be seen from the administrative requirements, legal requirements, technical requirements, time requirements, costs and organization. Substantially permission means a prohibition, order, approval or acquisition. This relates to the juridical aspects of the licensing system. For the most accurate use of a license must be carried out supervision and sanctioning the abuse of the licensing function. Supervision can be carried out in two forms which are preventive and repressive. Preventive supervision of the government can do in the form of observations, inspections and other forms whereas repressive supervision may in the form of administrative sanction in the form of cancellation, revocation of licenses, restitution and compensation, and criminal sanctions such as imprisonment and criminal fines. Based on this interpretation, a license is closely related to the purpose, legitimacy of authority, procedures, substance and law enforcement.

Efficiency and certainty to process a license, legal certainty over how to manage and at the same time own land and other sizes, and of course require certainty of the availability of infrastructure and have not been maximally carried out by local governments, in particular the North Sulawesi Province in implementing the Nawacita program, especially the third point, which emphasizes development starting from the periphery by strengthening regions and villages within the framework of the Unitary State of the Republic of Indonesia.

The complexity of these problems will lead to costs that are costly to investors and, if not resolved the government would lose its momentum. Specifically, in the legal sector of local governments should no longer be preoccupied with handling issues that are of low relevance to the main objectives. Actually, the purpose of granting autonomy to local governments is to improve services and better community welfare, development of democratic life, better and more equitable distribution of public services, respect for local culture and pay attention to the potential and diversity of the region. ${ }^{31} \mathrm{~A}$ focus on supervising and running the wheels of government is really needed when confronting and solving problems with nuances of uncertainty that boils down to the difficulty of creating macro stability.

There are a lot of laws in Indonesia overlap so need to reform the rules so as not to confuse investors, examples of some of the regulations are not in sync with the

\footnotetext{
Press, p. 135. p. 80 .

${ }^{31}$ Sarundajang, Sinyo Harry. (2005). Babak Baru Sistem Pemerintahan Daerah. Jakarta: Kata Hasta Pustaka,
} 
regulation of supporters among others Broking, the Law of the Republic of Indonesia Number 5 of 1960 on Basic Regulation principal Agraria is called a 30-year term and can be extended for a maximum of 20 years, but Law Number 25 of 2007 concerning Investment is disclosed that the Right to Build can be granted up to 80 years by being granted and extended in advance 50 years and renewed for 30 years. These different rules create confusion when employers consult with the National Land Agency when the Right to Build will expire. In addition to environmental licenses, it is stated in the Republic of Indonesia Government Regulation No. 142 of 2015 concerning Industrial Estates that industrial companies in industrial estates are exempted from licensing concerning disturbance, environment, location, place of business, allotment of land use, approval of land plan and analysis traffic impact. However, the reality of the environmental license must still be owned by business actors who refer to the Law of the Republic of Indonesia Number 32 of 2009 concerning Environmental Protection and Management and the Government of the Republic of Indonesia Number 27 of 2012 concerning Environmental Permits. Inequality between regulations on environmental licenses is an obstacle to investment activities. Government Regulation of the Republic of Indonesia Number 142 of 2015 cannot be implemented because the local government and investors are afraid of being subjected to criminal threats and fines as referred to in the Law of the Republic of Indonesia Number 32 of 2009.

Other rules that overlap and make it difficult for the business world to develop. Whereas regularity will only exist if there is certainty and legal certainty must be made. ${ }^{32}$ Investors hope that the government can improve the ranking of ease of doing business, so that such rules can be sought by the government so that entrepreneurs and investors have certainty and a sense of security.

Increased investment in the country depends also on the availability of manpower, therefore it is necessary to propose that local governments can spur improvement in the quality of the workforce with a dual system of education, which prioritizes the practice of the world of work. The regional government in the border region must allocate a large education fund to be used to develop a dual system through collaboration between schools, companies and the government to produce a workforce that is reliable and ready to use. Apart from the complexity of the issue of regional autonomy, in terms of investment law efforts to improve the investment climate are quite important steps in building market confidence because it is realized that Indonesia is included in the high country risk category for the entry of foreign investment flows.

The government and business actors in the regions must realize the need to seek a conducive investment climate in the region to attract regional investment

${ }^{32}$ Rasjidi, Lili, \& Putra, I. B. Wyasa. (2003). Op. Cit., p. 48. 
flows because if it is not realized then the existing investment has the opportunity to withdraw and relocate to countries that promise investment security. If there are investors who enter certain regions, it is not certain that they will dare to invest directly in the long term with the consideration that at any time undesirable things are related to country risk, relocation is easy to do and investment risk can be minimized. ${ }^{33}$

Many large investments are threatened due to lack of legal certainty. The targeted investment value will not be achieved if the certainty of the contract and the legal basis is not implemented properly. Investment policies made by the central government are often hampered by regional autonomy through regional regulations and other bureaucracies. Many Perda is inconsistent with higher regulations because regional policies often hamper investment inflows. Local regulations that do not refer to higher regulations can cause disharmony in legal products, but national and global factors such as political stability, national security and resilience, rule of law and consistency of local government programs are determinants. ${ }^{34}$ This is due to the implementation of regional autonomy which is not conducive and efficient enough. The obstacles that are often experienced by investors include policy inconsistencies, complicated and expensive bureaucracy, regional policy uncertainty, many levies including illegal levies, communal conflicts to land disputes. To overcome economic problems, especially in investing, the government is taking steps to encourage the competitiveness of national industries, through deregulation, bureaucratization, and law enforcement and business certainty.

There are ways in creating how important it is to provide legal certainty so that the desire to invest in Indonesia can be realized, especially in border areas, which is to reorganize the course of the organization and policies that impede legal certainty, to break the chain that has no effectiveness in launching and facilitating investment, the duration of the implementation of the licensing administration system is accelerated so as to produce an effective and efficient settlement pattern, ensuring all functions involved in it have the intensity and capacity in favor of economic development in the perspective of regional autonomy in developing border areas based on people's welfare, in addition to that department which has a low scope of endeavor so as not to hold authority in handling licenses so as to make it easier for investors to invest.

The importance of this method is to strengthen everything related to the ease of investing in Indonesia, especially in border areas in North Sulawesi, which has not been very convincing, one of which is the availability of adequate infrastructure. Obstacles like this that must be resolved by the government, especially local governments. As

\footnotetext{
-52 .

${ }^{33}$ Rais, Syaukani Hasan. (2003). Welcome Investor: Di Era Otonomi Daerah. Jakarta: Nuansa Madani, p. 51 ${ }^{34} \mathrm{lbid}$
} 
an element of the nation in which related to development at this time feel that this situation must be changed as soon as possible, and need bureaucratic reform that aims to create a professional government bureaucracy with adaptive, integrated, highperformance, clean and free from corruption, collusion and nepotism, able serving the public and based on the code of ethics of the state apparatus. ${ }^{35}$

The obstacles that result in the non-optimal functioning of the economy to run well at any scale must be pushed aside so that the wheels and economic policies can be sustainable. These barriers must be cut if the local government wishes to achieve economic growth in moderate numbers. In the future, after improvements are made, it is expected that our country's economic forecasts can run faster. This can happen if bureaucratic reforms characterized by the realization of collision-free government, improved quality of public services and increased capacity and accountability of bureaucratic performance are achieved. ${ }^{36}$ No more threats are found that have the potential to disrupt economic policy so that it impacts on welfare so that by carrying out law enforcement and certainty in investing will produce a form of a resilient economy. Exploring the existing economic potentials and the strong handling of the legal settlement will form a new economic cycle.

Economic turnover by prioritizing positive economic growth based on people's welfare to drive the flow of goods and services and increase regional production which in turn was followed by an increase in various leading sectors of the border region in North Sulawesi such as marine, agriculture, trade, tourism. In Indonesia, domestic investors also need foreign investors, especially those related to the exploitation of natural resources which are often considered to conflict with national interests, whereas on the other hand, Indonesia is in dire need of foreign investment to drive the economy, especially during the economic slowdown.

Over the years it has been proven that foreign investment in Indonesia has succeeded in absorbing mass labour, increasing state revenues and human resource capabilities because there is a transfer of knowledge and technology that in many ways, foreign investment is not just investment/capital, but also the creation of valueadded to improving community welfare. on the contrary, the strong influence of public opinion and weak investor protection makes foreign investors reluctant to increase their investment, so that legal certainty and protection is needed for all parties, both society and the state and foreign investors so that the benefits can be felt by all parties.

The study of the rules on investment needs to be reviewed and adjusted to the conditions and comprehensive evaluation so that foreign investment in Indonesia wants to expand its business wing in the Indonesian border region so that it can

${ }^{35}$ Etzioni-Halevy, Eva. (2011). Birokrasi \& Demokrasi: Sebuah Dilema Politik. Yogyakarta: Total Media, p. 109. ${ }^{36} \mathrm{lbid}$. 
survive and obtain more benefits, while the national interest is more maintained and can be optimized. Besides that, Indonesia also needs to follow the trend of investment policies in the world, so that investment in the country can grow and develop quickly, if the policy framework in Indonesia is far behind other places, it is difficult to expect investment to grow high. Although in the current era of globalization, economies between countries are very open and interdependent, although several developing countries try to maintain their existence by protecting trade and industry, especially those closely related to the livelihoods of many people.

\section{CONCLUSION}

Legal protection in the context of investment law means providing legal protection to investors in carrying out their investment activities and providing legal certainty consistently. Investment policies made by the central government are often hampered by regional autonomy because policies in the regions often hamper the entry of investment. This is due to the implementation of regional autonomy which is not conducive and efficient enough. Barriers that are often experienced by investors, including inconsistency of policy, regional policy uncertainty, and land disputes. To solve the economic problems, especially in investment, the government has taken steps to boost the competitiveness of the national industry, through deregulation, de-bureaucratization, as well as law enforcement and business certainty. This requires steps that provide legal certainty so that the desire to invest in Indonesia can be realized, especially in border areas, which is to reorganize the course of the organization and policies that impede certainty, break links that do not have the effectiveness in launching and facilitating investment, the importance of the steppingstone to do is to consolidate everything related to the ease of investing in the country can be resolved. Investors themselves are aware that the investment climate in Indonesia, especially in the border areas in North Sulawesi has not been so convincing, one of which the availability of adequate infrastructure. Concern and seriousness of local governments on development priorities in the border areas need to be improved by the provision of adequate infrastructures such as the security of legal certainty and legal protection of investors in encouraging activity. Suggestions from this research are the need to reform the laws and regulations that govern regional regulations in North Sulawesi related to investment management in border areas that can provide certainty and legal protection for investors.

\section{REFERENCE}

Atmosudirdjo, S. Prajudi. (1990). Dasar-Dasar Administrasi Negara. Jakarta: Ghalia Indonesia. 
Baharuddin, Hamzah. (2008). Hak Gugat Lembaga Swadaya Masyarakat (LSM) dalam Rangka Kontrol terhadap Pelayanan Publik. Makassar: PT. Umitoha Ukhuwah Grafika.

Etzioni-Halevy, Eva. (2011). Birokrasi \& Demokrasi: Sebuah Dilema Politik. Yogyakarta: Total Media.

Fahmal, A. Muin. (2006). Peran Asas-Asas Umum Pemerintahan yang Layak dalam Mewujudkan Pemerintahan yang Bersih. Yogyakarta: UII Press.

Hadjon, Philipus M., et al. (Eds.). (2008). Pengantar Hukum Administrasi Indonesia. Yogyakarta: UGM Press.

Halwani, Hendra. (2002). Ekonomi Internasional dan Globalisasi Ekonomi. Bogor: Ghalia Indonesia.

Hartono, C. F. G. Sunaryati. (1985). Hukum Ekonomi Pembangunan Indonesia. Bandung: Bina Cipta.

Indroharto. (1994). Pentingnya Asas-Asas Umum Pemerintahan yang Baik. In Paulus Effendi Lotulung (Ed.), Asas-Asas Umum Pemerintahan yang Baik. Bandung: PT. Citra Aditya Bakti.

Kemitraan Partnership. (2011). Kebijakan Pengelolaan Kawasan Perbatasan Indonesia. In Partnership Policy Paper No. 2/2011. Jakarta: The Partnership for Governance Reform. Retrieved from http://www.kemitraan.or.id/policy-paper-no-22011kebijakan-pengelolaan-kawasan-perbatasan/\#

Kusumaatmadja, Mochtar. (2002). Konsep-Konsep Hukum dalam Pembangunan (Otje Salman \& Eddy Damian Eds.). Bandung: PT. Alumni.

Kusumohamidjojo, Budiono. (1999). Ketertiban yang Adil: Problematik Filsafat Hukum. Jakarta: Grasindo.

Manan, Bagir. (2001). Menyongsong Fajar Otonomi Daerah. Yogyakarta: UII Press.

Mardiasmo. (2004). Otonomi dan Manajemen Keuangan Daerah. Yogyakarta: CV. Andi Offset.

Margono, Sujud. (2008). Hukum Investasi Asing Indonesia. Jakarta: Novindo Pustaka Mandiri.

Law of the Republic of Indonesia Number 5 of 1960 concerning Basic Rules on Agrarian Principles. State Gazette of the Republic of Indonesia, Number 104 of 1960. Supplement to the State Gazette of the Republic of Indonesia, Number 2043. 
Law of the Republic of Indonesia Number 25 of 2004 concerning National Development Planning System. State Gazette of the Republic of Indonesia, Number 104 of 2004. Supplement to the State Gazette of the Republic of Indonesia, Number 4421.

Law of the Republic of Indonesia Number 17 of 2007 concerning the National Long-Term Development Plan 2005 - 2025. State Gazette of the Republic of Indonesia, Number 33 of 2007. Supplement to the State Gazette of the Republic of Indonesia, Number 4700.

Law of the Republic of Indonesia Number 25 of 2007 concerning Investment. State Gazette of the Republic of Indonesia, Number 67 of 2007. Supplement to the State Gazette of the Republic of Indonesia, Number 4724.

Law of the Republic of Indonesia Number 32 of 2009 concerning Environmental Protection and Management. State Gazette of the Republic of Indonesia, Number 140 of 2009. Supplement to the State Gazette of the Republic of Indonesia, Number 5059.

Rais, Syaukani Hasan. (2003). Welcome Investor: Di Era Otonomi Daerah. Jakarta: Nuansa Madani.

Rasjidi, Lili, \& Putra, I. B. Wyasa. (2003). Hukum Sebagai Suatu Sistem. Bandung: CV. Mandar Maju.

Regulation of the President of the Republic of Indonesia Number 2 of 2015 concerning the National Medium-Term Development Plan 2015 - 2019. State Gazette of the Republic of Indonesia, Number 3 of 2015.

Regulations of the Capital Investment Coordinating Board of the Republic of Indonesia Number 6 of 2018 concerning Guidelines and Procedures for Licensing and Investment Facilities. State Gazette of the Republic of Indonesia, Number 934.

Regulations of the Capital Investment Coordinating Board of the Republic of Indonesia Number 7 of 2018 concerning Guidelines and Procedures for Controlling the Implementation of Investment. State Gazette of the Republic of Indonesia, Number 935.

Regulations of the Government of the Republic of Indonesia Number 27 of 2012 concerning Industrial Estate. State Gazette of the Republic of Indonesia, Number 47 of 2012. Supplement to the State Gazette of the Republic of Indonesia, Number 5285.

Regulations of the Government of the Republic of Indonesia Number 142 of 2015 concerning Industrial Estate. State Gazette of the Republic of Indonesia, Number 365 of 2015. Supplement to the State Gazette of the Republic of Indonesia, Number 5806. 
Riyanto, Astim. (2003). Filsafat Hukum. Bandung: Yapemdo.

S., Salim H., \& Sutrisno, Budi. (2008). Hukum Investasi di Indonesia. Jakarta: PT. Raja Grafindo Persada.

Saleh, Ismail. (1990). Peranan Konglomerasi sebagai Pelaku Ekonomi dalam Rangka Pembangunan Nasional. In Pokok-Pokok Pikiran mengenai Pengaturan Persaingan Sehat di Dunia Usaha (20 February ed.). Jakarta: Universitas Tarumanagara.

Samidjo. (1986). Ilmu Negara. Bandung: CV. Armico.

Sarundajang, Sinyo Harry, \& Kuncoro, Mudrajad. (2011). Geostrategi: Sulawesi Utara Menuju Pintu Gerbang Indonesia di Asia Pasifik. Jakarta: Kata Hasta Pustaka.

Sarundajang, Sinyo Harry. (2005). Babak Baru Sistem Pemerintahan Daerah. Jakarta: Kata Hasta Pustaka.

Sembiring, Sentosa. (2010). Hukum Investasi: Pembahasan Dilengkapi dengan UU Nomor 25 Tahun 2007 tentang Penanaman Modal. Bandung: Nuansa Aulia.

Siagian, Sondang P. (2005). Administrasi Pembangunan: Konsep, Dimensi, dan Strateginya. Jakarta: Bumi Aksara.

Soekanto, Soerjono. (1976). Beberapa Permasalahan Hukum dalam Kerangka Pembangunan di Indonesia. Jakarta: Yayasan Penerbit Universitas Indonesia.

Sukirno, Sadono. (2006). Ekonomi Pembangunan: Proses, Masalah, dan Dasar Kebijakan. Jakarta: Kencana Prenada Media Group.

Syahrani, Riduan. (2004). Rangkuman Intisari IImu Hukum. Bandung: PT. Citra Aditya Bakti.

The 1945 Constitution of the Republic of Indonesia.

Tjokroamidjojo, Bintoro. (2000). Good Governance: Paradigma Baru Manajemen Pembangunan. Jakarta: UI Press. 